Volume 8, No.1.6, 2019

International Journal of Advanced Trends in Computer Science and Engineering

Available Online at http://www.warse.org/IJATCSE/static/pdf/file/ijatcse4981.62019.pdf

https://doi.org/10.30534/ijatcse/2019/4981.62019

\title{
Identification of Networking Connectivity Components in doing Seniorpreneurship
}

\author{
Marlina Muhamad ${ }^{1}$, Fariza Hanis Abd Razak ${ }^{2}$, Haryani Haron ${ }^{3}$ \\ ${ }^{1}$ Faculty of Business and Management, Universiti Teknologi MARA Cawangan Kedah, Malaysia, \\ marlina326@uitm.edu.my \\ ${ }^{2}$ Faculty of Computer and Mathematical Sciences, Universiti Teknologi MARA Shah Alam, Malaysia, \\ fariza@tmsk.uitm.edu.my \\ ${ }^{3}$ Faculty of Computer and Mathematical Sciences, Universiti Teknologi MARA Shah Alam, Malaysia, \\ haryani@ tmsk.uitm.edu.my
}

\begin{abstract}
This paper presents one of the crucial capitals owned by seniorpreneurs that built up over their working careers known as social capital. In this study, one of the possible components of social capital which influence seniorpreneurship is by having vast networking and linkages. Hence, this study identifying formal and informal networks within networking connectivity are essentials to strong and sustainable seniorpreneurship activity. It can be done by incorporating formal and informal networking connectivity model in order to strengthening their social capital in doing seniorpreneurship. The research employed systematic analysis from literature searched from electronic databases, hand pick, and other relevant works, summarize information gathered and finally interpreted the information. In the present paper the component of networking is investigated from entrepreneurial perspective in the field of entrepreneurship since efforts to review the networking connectivity for seniorpreneurs are scarce. Thus, the component of network needed in doing seniorpreneurship are rooted in entrepreneurial literature known as formal and informal networks. Thus, this result enriches previous literature about seniorpreneurs and their vast networking and linkages.
\end{abstract}

Key words : Entrepreneurship, formal and informal network, seniorpreneurship, social capital.

\section{INTRODUCTION}

Given that older adult are now continue to live longer, and likely facing an insufficient in retirement income or expectations, apparently more older adult are deciding to enrolled their own business rather than get paid working for others [1]. Engaging longer in workforce or in other meaningful activities like becoming an entrepreneur at later age is an effective way to increase productive ageing [2]. An entrepreneur who's aged between 50 to 65 have a rapid spreading proportion of entrepreneurial activity than those who's aged between 20 to 34 [1]. Despite large volume of studies on entrepreneurship among young people in Malaysia
[3], there is inadequate studies of seniorpreneurs in Malaysia. Older adult who become entrepreneur after retirement age is defined as senior entrepreneur by [4] as senior people aged 60 years above who have or are making their own business either before or after retirement. They may start a single enterprise, as professional advisors, financiers, agents or freelancers, or hook up with a few colleagues to create a new business deal [5]. Some of the older adult also may start to work as hobbies first which later on flourished and become an income generator. Older adult who have an obsession, hobbies, or passion that produces something people are happy to pay for, creating a business that they will love running. According to [5], the linkages, resources and proficiency older adult develop over decades of work will be an asset that successful start-ups belong to senior entrepreneurship. The literature on support networks highlighted that there are variety of network sources in which entrepreneurs obtain resources for their businesses. [6] mentioned a set of users who frequently interact with each other and share the same preferences and interests is defined as a community in a social network, for example the process of buying and selling.

Understandably, the extent literature suggests entrepreneurial assets which include possessing experience, knowledge, and strong financial position were drivers that is related to must have capitals to become an entrepreneur [7]. However, another important asset is a having strong networks and linkages would enable entrepreneurs to compensate for lack of human and financial assets which proven in the context of entrepreneurship [8]. So far, the literature addresses the benefits of having vast networks and linkages that seniorpreneurs possess, however, it is not well known on how this benefit can be used to support their start-up business.

This article aims to narrow down the gap by identifying components within networking connectivity in doing seniorpreneurship. The work fills an important gap in the literature, with most review examining the components of networking conectivity through entrepreneurship studies. To develop a relevant review, the literature study was geared by the main research question, what components of networking connectivity can be adapted by seniorpreneurs in doing seniorpreneurship? Based on the above questions, the main 
focus of this study is to identify the existing literature on networking connectivity components needed by seniorpreneurs and the methods employed.

\section{RELATED STUDIES}

\subsection{Seniorpreneurship}

The current research area into the phenomena of "senior entrepreneur" (also extensively termed as "senior entrepreneurs", "older entrepreneurs", "grey entrepreneur", "third age entrepreneurs", "elder entrepreneurs" and "senior-preneurs"), yielding on researches from European country and Australia. There are numbers of potential drivers that appear to have an impact on the activities and the likelihood of success in doing seniorpreneurship. The current definition of seniorpreneur is taken by [4], describe people 60 years or older who have or are considering starting their own business either before or after retirement.

To avoid subjective discrete categorizations of an entrepreneur, the seniorpreneurs in this study follows the use of terminology and definition commonly used in Malaysia where the older adult is defined as those who are 60 years old and above, the cut-off age adopted by the most influential official international organization, the United Nations [9]. Therefore, people aged over 60 and above participate in entrepreneurial activity is termed as "seniorpreneurship" is used to describe the process.

\subsection{Possessing Vast Network and Linkages}

The extent literature suggests entrepreneurial capital include possessing vast network and linkages apart from human and financial capital were some encouraging factors that is related to seniorpreneurship [7]. [10] suggested seniorpreneurs able to secure a list of networks consist of useful contacts during their working lives. The advantages of having existing contacts and networks, it help give rise to a ready-made customer base when the business is launched including reduce the expense for paid advertising [11]. Similarly, having a network from government agencies, is also seen as an important support mechanism to spur seniorpreneurship.

Nevertheless, if potential seniorpreneurs have become disconnected from their workplace ties through a period of retirement or a period of unemployment, this can cause a challenges in networking where they have to start from basic just like young entrepreneurs [12]. Once retired, older adults may find it hard to maintain or increase membership of their network. However, by doing seniorpreneurship may allow them to sustain and increase more networks. Repeated studies indicate that in order to have a beneficial outcomes, networking processes and structures are always of importance to entrepreneurs.

\section{METHODOLOGY}

Step by step descriptions regarding the methods of this study on how the study was performed as listed below. This study seeks to clarify the component within networking connectivity in doing seniorpreneurship. The literature review involved the following steps:

\section{A. Literature search}

By performing a preliminary search of the literature is the first step in writing a systematic overview of this study. This initial process allows researcher write down to refine topic and objective of the study. Researcher performed a broad initial search. The following electronic databases were searched namely Scopus, Web of Science, IEEE Xplore, ACM Digital Library, and Google Scholar. The following keywords were used in various combinations including entrepreneurs, entrepreneurship, seniorpreneurs, older entrepreneurs, grey entrepreneur, third age entrepreneurs, elder entrepreneurs, seniorpreneurship, entrepreneurship, factors, drivers, networks, networking, social capital, resources, and linkages was conducted. Researcher decided to conduct a broad search to ensure that researcher would identify as much relevant literature as possible.

\section{B. Selection criteria}

All types of paper including conceptual and empirical were part of this review process that enabled a more holistic understanding of the literature. The literature review contains articles up until 2019. During the review process, the studies were extracted, monitored then synthesized in terms of overall themes. Researcher also excluded duplicate articles, technical-focused articles (those focusing on technical stability, configurations, algorithms, and data structure). The number of articles decreased due to the exclusion criteria (Table 1). To avoid any confusion and difficulty in translating, only articles published in English are selected for review.

Table 1: Inclusion and Exclusion Criteria

\begin{tabular}{|c|c|c|}
\hline Criterion & Inclusion & Exclusion \\
\hline $\begin{array}{l}\text { Literature } \\
\text { type }\end{array}$ & $\begin{array}{l}\text { Non-scientific } \\
\text { journal articles }\end{array}$ & $\begin{array}{c}\text { Scientific journal } \\
\text { articles }\end{array}$ \\
\hline Language & English & Non-English \\
\hline Timeline & Up until 2019 & None \\
\hline $\begin{array}{l}\text { Countries and } \\
\text { territories }\end{array}$ & $\begin{array}{c}\text { Developing and } \\
\text { developed countries }\end{array}$ & $\begin{array}{l}\text { Non-developed } \\
\text { countries }\end{array}$ \\
\hline Subject area & $\begin{array}{c}\text { Social Studies, } \\
\text { Sociology } \\
\text { Perspective, } \\
\text { Computer Science }\end{array}$ & $\begin{array}{l}\text { Other than Social } \\
\text { Studies, Sociology } \\
\text { Perspective, } \\
\text { Computer Science }\end{array}$ \\
\hline
\end{tabular}

\section{Critical assessment}

The remaining articles were screened to get a feel for the literature in this field. The majority of the articles were irrelevant to the research questions. In this step, all the articles are examined thoroughly to ensure its fit the criteria 
determined. The examination was done manually by the researcher. As a result of the search 16 articles were included in this review.

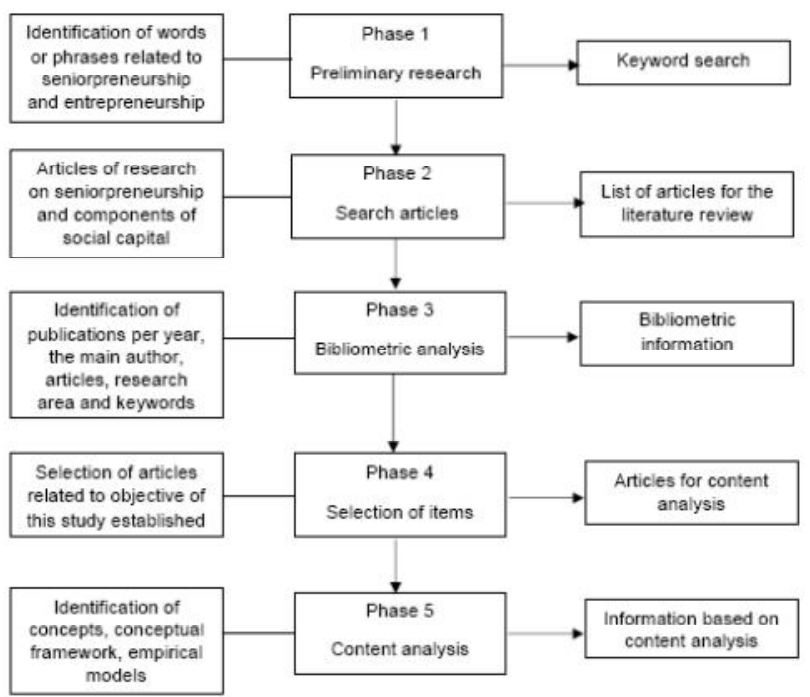

Figure 1: Flowchart of the literature selection process for the present article

\section{Data extraction and analysis}

The selected articles were analyzed qualitatively, drawing on the central procedures used in thematic analysis to provide a better understanding and identifying the components of networking connectivity in seniorpreneurship. A thematic analysis was used to categorize the research into main themes. These themes enable gaps in the literature to be identified that paves the way for future research. Initial codes were identified, extracted, and entered manually into paper (qualitative data analysis). The codes were organized into the following themes: formal and informal networks (primary, secondary, and tertiary).

\section{RESULTS}

Many of the publications addressed several of the identified themes, which are presented below along with discussion of the findings. The literature on components of networking connectivity in entrepreneurship identifies the key success factors that are essential in doing entrepreneurship that seem imperative to seniorpreneurs namely formal network, and informal networks (primary, secondary, tertiary). The results provided a comprehensive analysis of the networking and its elements affecting seniorpreneurship.

\section{DISCUSSION}

The peer-reviewed literature reporting an important asset is possessing social capital (such as networks, linkages and personal contacts). The successful of seniorpreneurs were suggested by scholars due to their higher levels of human, social, and financial capital, on average, than young entrepreneurs [5]. These advantages, built up over the course of seniorpreneur's life, make it easier to access financial support for business startup and tap into seniorpreneurs' personal and professional networks to achieve business growth [5]. The literature on support networks highlighted that there are variety of network sources in which entrepreneurs obtain resources for their businesses. The existing networks and contacts from seniorpreneurs' sources are typically categorized as formal and informal networks [13]; personal and impersonal networks [14]; primary, secondary and tertiary [15], [16]; and public, personal and professional sources [17].

The network portrays an essential role in doing entrepreneurship, including on how to find the available human and financial resources [8]. The conceptual framework reveals that entrepreneurs need personal and extended networks to motivates them in doing entrepreneurship. The term of "networks" can be understood as approaches of interactions or relationships, where the nodes consist of actors, and the edges consist of relationships or interactions between these actors [6]. According to [18], in entrepreneurship studies, network and linkages is a set of actors connected by a set of repeated interaction either formal or informal.

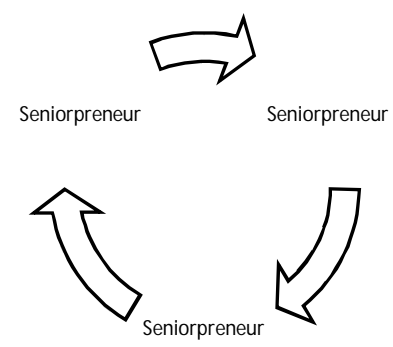

Figure 2: Social network diagram of seniopreneurs

\subsection{Formal Network}

[19] considered that better informal networking and support may be lead by formal social network at first, which later strengthen by social norms namely co-operation and trust. However, it is said that there is no need for informal networks at the beginning if there is at presence consist of rich associative ties of formal network [20]. [21] revealed in friends-based networks, people are becoming formal members via their friends. This finding is in accordance with [22], [23], and [24] confirm that through their friends people usually decide about formal networking. [25] mentioned individual activities affected by their close relationships with network ties and a broader social environment. When a new business reaches its startup phase, an entrepreneurial network becomes a business focused network that relates to emerging business relations with customers, buyers, and suppliers. This network gradually changes to a more formal strategic network, which is typical for the ongoing business phase. [13] considers banks, accountants, lawyers, local government, chambers of commerce, realtors and small business administrators as formal sources. [13] mentioned after business start-up, to gain access to requisite business information, entrepreneurs increasingly rely on professional bankers, accountants, lawyers, suppliers, government 
agencies, etc. Entrepreneurs tap into knowledge, information, and resources, from a wider set of relationships than those to whom they are directly connected from this type of network known as weak ties. Extended networks are the collective result when interconnected personal networks are examined. Extended network also known as formal network [25]. Formal entrepreneurial networks are associations of businesses or functions within them, like institutions, organizations, or groups [25]. This type of network become the source of information regarding regulatory matter that impact a business, technical developments, administration, and to share results [25]. To reach out the public and influencing government policy, formal networks are considered as an effective connectivity needed by entrepreneurs [25].

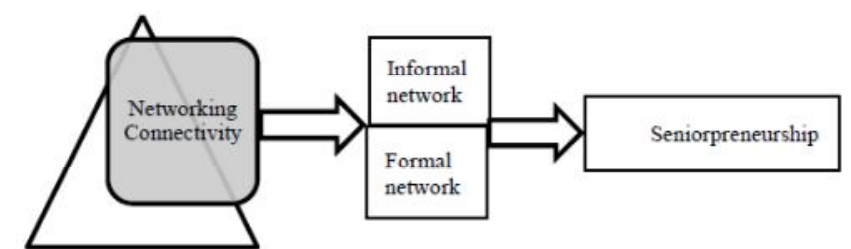

Figure 3: Conceptual framework network connectivity contributes towards seniorpreneurship

\subsection{Informal Network}

[26] emphasized that an entrepreneurial network develops during the pre-startup phase characterized by strong social informal dependencies. Personal or informal networks is known as entrepreneurial networks which start with the entrepreneur's established web of relationships consist of family, friends, and acquaintances. Possessing a vast network and linkages including formal and informal networks can influence the entrepreneurial process at both the start-up and operating stages [7]. In other words, senior entrepreneurs rely on their personal networks to assist in the start-up process as well as gain access to markets. This type of network in which entrepreneurs can "count on" is built on strong ties and relations [27]. [13] considers informal sources of help consist of business contacts, other contacts, family and personal friends. Studies by [15], and [16], categorize three ways of entrepreneurial networks. They consider family and friends are primary relations to consist. The relationships with family and friends are closest to the entrepreneur physically and emotionally and linked with more than one type of activity. Secondary relations in which tend to be linked to a precise activity include acquaintances and refers to the business, social, religious and political groups. Scholars emphasize that business, social, religious and political groups are always informal and will provide fertile ground for networking and will later become primary contacts. Meanwhile, reading materials, seminars, exhibitions etc. known as tertiary relations where entrepreneurs can acquire knowledge and ideas for their businesses.

In the more general studies of entrepreneurial during start-up, the importance of family and friends has been highlighted. However, as the business evolves, the network grows and the entrepreneur increasingly develops and utilizes more from business relationships [28]. [29] note that, entrepreneurs rely heavily on informal network of friends, family members, and social contacts to gather information at an early stage. Five broad categories of personal network that termed as 'secondary' network were identified [30]: Regarding these five networks, these are all informal rather than formal. They are secondary, because the entrepreneur is tapping into these existing networks, perhaps with only one or two links with each network. According to [30], the primary informal network of the entrepreneur is made up of all his or her direct personal links, and some of these links enable the entrepreneur to connect to pre-existing networks (scientific and technical networks, profession networks, user networks, friendship networks, and recreation networks), hence why these are secondary networks.

- scientific and technical networks are organized around scientific or technological domains, and include academic and corporate researchers;

- profession networks are comprised of individuals within a given profession, such as medicine or education, and bound by 'professional ethics of co-operation';

- user networks are evolved with the end-users of a firm's products;

- friendship networks refer to the personal networks of individual based predominantly on friendship; and

- recreation networks are particularly type of friendship network whose cohesion arises from the mutual sense of attachment to some recreational activity, such as sailing, mountaineering or rugby, where the feelings of challenge, achievement and comradeship through participation, create and maintain personal bonds.

Table 2: Networking Connectivity Components

\begin{tabular}{l|l|l}
\hline \multirow{5}{*}{ Formal Network } & \multicolumn{1}{|c}{$\begin{array}{c}\text { Networking Connectivity } \\
\text { Components }\end{array}$} \\
\hline \multirow{5}{*}{ Informal Network } & $\begin{array}{l}\text { Institutions, organizations, or groups } \\
\text { (Banks, accountants, lawyers, local } \\
\text { government, chambers of commerce, } \\
\text { realtors, and small business } \\
\text { administrators) [13] }\end{array}$ \\
\cline { 2 - 3 } & Secondary & $\begin{array}{l}\text { Family and friends [15], } \\
\text { [16] } \\
\text { social, religious and } \\
\text { political groups) [15], } \\
{[16]}\end{array}$ \\
\cline { 2 - 3 } & Pertiary & $\begin{array}{l}\text { Reading materials, } \\
\text { seminars, exhibitions, etc. } \\
{[15],[16]}\end{array}$ \\
\hline
\end{tabular}




\section{CONCLUSION}

The objective of this review was to identify the components of networking connectivity on seniorpreneurship as a way to synthesize past research that can provide future research suggestions. Due to the number of interests in studies about productive ageing and older adult that tapped into entrepreneurship realm, it is important in which more research should be done in focusing senior entrepreneurs. There is little research existing regarding on how their vast networking and linkages can be used to support their start-up business. Seniorpreneurs are among disadvantaged group that needed more investigation. The main contribution of this paper is to identifying where the literature on seniorpreneur's networking connectivity is heading. The findings from this paper will be of interest to the sociology and entrepreneurship field as this study moves to adding more studies about seniorpreneurs.

\section{ACKNOWLEDGEMENT}

The researcher would like to thank the two anonymous reviewers, for their careful reading of the manuscript and their many insightful comments and suggestions.

\section{REFERENCES}

1. A. Maritz, "Senior Entrepreneurship in Australia: An Exploratory Approach. International Journal of Organizational Innovation,” vol. 7(3), pp. 6-18, 2015.

2. B. A. Belbase, and G. T. Sanzenbacher, "Cognitive Aging and Ability to Work: Age and Job Performance. How Do Most Workers Stay," vol. 16, 2016.

3. S. N. Daud, N. A. Ismail, M. Abdullah, and N. A. Hassan, "Entrepreneurship Traits among Engineering Students: Instrument Development and Validation Procedure using Structural Equation Modeling," International Journal of Advanced Trends in Computer Science and Engineering, vol. 8 (2), pp. 235-240, 2019.

https://doi.org/10.30534/ijatcse/2019/21822019

4. A. Maritz, "Senior entrepreneurship themes: An Australian Perspective," International Journal of Organizational Innovation, vol. 9, pp. 206-221, 2017.

5. J. Maxwell, "Seniorpreneur: It's never too late to start. A Guide by Joanna Maxwell. Reinvent your working life," https://www.joannamaxwell.com.au/wp-content/uploads /jm-seniorpreneur.pdf, 2016.

6. M. Dhibi, J. Pandey, and A. Al Kilani, "Majority Vote method for preferences detection: Application for Social Networks," International Journal of Advanced Trends in Computer Science and Engineering, vol. 8 (1), pp. 42-53, 2019.

https://doi.org/10.30534/ijatcse/2019/08812019

7. N. H. Ahmad, A. M. Nasurdin, H. A. Halim, and P. Seet, "Silver entrepreneurship agenda in Malaysia: A proposed model for productive aging," 2012.

8. P. J. Ferri, D. Deakins, and G. Whittam, "The measurement of social capital in the entrepreneurial context," Journal of Enterprising Communities: People and Places in the Global Economy, vol. 3 (2), 2009.

9. United Nations, Department of Economic and Social Affairs, Population Division, "World Population Ageing,"

http://www.un.org/en/development/desa/population/publ ications/pdf/ageing/WorldPopulationAgeing2013.pdf. 2013.

10. A. De Bruin, and E. McLaren, "An Exploration of Networks of the Self-Employed," Proceedings of the 15th Conference of the Small Enterprise Association of Australia and New Zealand, 21-24 Sept., Adelaide, South Australia, 2002.

11. N. H. Ahmad, A. M. Nasurdin, H. A. Halim, and S. K. Taghizadeh, "The Pursuit of Entrepreneurial Initiatives at the "Silver" Age: From the Lens of Malaysian Silver Entrepreneurs," Procedia - Social and Behavioral Sciences, vol. 129, pp. 305-313. https://doi.org/10.1016/j.sbspro.2014.03.681, 2014.

12. T. Kautonen, S. Down, and M. Minniti, "Ageing and entrepreneurial preferences," Small Business Economics, vol. 42(3), pp. 579- 594, 2013.

13. S. Birley, "The role of networks in the entrepreneurial process," Journal of Business Venturing, vol. 1 (1) pp. 107-117, 1985.

14. L. R. Smeltzer, and G. L. Fann, "Gender Differences in External Networks of Business Owner/Managers," Journal of Small Business Management, pp. 25-32, 1989.

15. L. J. Filion, "Entrepreneurial Performance, Networking, Vision and Relations," Journal of Small Business and Entrepreneurship, Vol. 7, No. 3, pp. 3-12, 1990.

16. A. Hand, and M. Tomblin, "A Comparative Study of Entrepreneurial Networking in Scotland and Massachusetts," Quadrangle Consulting Limited, London, 1993.

17. A. Cooper, T. Folta, and C. Woo, "Information Acquisition and Performance by Start-up Firms," Frontier of Entrepreneurship Research, Wellesley, Mass: Babson College, pp. 276-289, 1991.

18. R. D. Putnam, "Bowling Alone: The Collapse and Revival of American Community," New York: Simon and Schuster, 2000. https://doi.org/10.1145/358916.361990

19. F. Fukuyama, "Trust: The Social Virtues and the Creation of Prosperity," New York: Free Press, 1995.

20. C. Fischer, "The Urban Experience," New York: Harcourt Brace Jovanovich, 1975.

21. W. van Oorschot, W. Arts, and J. Gelissen, "Social Capital in Europe: Measurement and Social and Regional Distribution of a Multifaceted Phenomenon," Acta Sociologica, vol. 49, no. 2, pp. 149-167, 2006.

22. C. Kenny, "Political Participation and Effects from the Social Environment," American Journal of Political Science, vol. 36, no. 1, pp. 259-267, 1992.

23. R. Huckfeldt, "Political Participation and the Neighborhood Social Context," American Journal of Political Science, vol. 23, no. 3, pp. 579-592, 1979.

24. D. C. Mutz, "The Consequences of Cross-cutting Networks for Political Participation," American Journal of Political Science, vol. 46, no. 4, pp. 838-855, 2002. 
25. S. Kwon, and P. Arenius, "Nations of entrepreneurs: A social capital perspective," Journal of Business Venture, vol. 25, pp. 315-330, 2010.

26. J. E. Butler, and G. S. Hansen, "Managing Social Network and Entrepreneurial Benefits," Frontier of Entrepreneurship Research, Wellesley, Mass: Babson College, pp. 403-404, 1988.

27. P. Dubini, and H. Aldrich, "Personal and Extended Networks are Central to the Entrepreneurial Process," Journal of Business Venturing, vol. 6, pp. 305-313, 1991.

28. A. Hampton, S. Cooper, and P. McGowan, "Female Entrepreneurial Networks and Networking Activity in Technology-based Ventures: An Exploratory Study," International Small Business Journal, vol. 27(2), pp. 193-214, 2009.

29. S. Birley, S. Cromie, and A. Myers, "Entrepreneurial networks in Northern Ireland," Ulster Business School, Belfast, 1991.

30. S. Conway, "Informal Networks of Relationships in Successful Small Firm Innovation," in D. Jones-Evans and M. Klofsten (eds.), Technology, Innovation and Enterprise: The European Experience, London: MacMillan, pp. 236-273, 1997.

https://doi.org/10.1007/978-1-349-25770-6_8 